\title{
RAZUMIKHIN METHOD TO DELAY DIFFERENTIAL EQUATIONS WITH NON-INSTANTANEOUS IMPULSES
}

\author{
Ravi Agarwal, Snezhana Hristova and Donal O’REgan
}

\begin{abstract}
The stability for delay differential equations with non-instantaneous impulses is studied using Lyapunov like functions and the Razumikhin technique. In these differential equations we have impulses, which start abruptly at some points and their action continue on given finite intervals. Sufficient conditions are given and they use comparison results for nonlinear scalar non-instantaneous impulsive equation without any delay. Examples are given to illustrate our stability properties and the influence of non-instantaneous impulses on the behavior of the solution.
\end{abstract}

Mathematics subject classification (2010): 34A34, 34K45, 34A08, 34D20.

Keywords and phrases: Non-instantaneous impulses, stability, Razumikhin technique, Lyapunov functions.

\section{REFERENCES}

[1] R. P. AgARWAL AND S. HRISTOVA, Strict stability in terms of two measures for impulsive differential equations with 'supremum', Appl. Anal. 91, 7, (2012), 1379-1392.

[2] R. Agarwal, D. O'Regan And S. Hristova, Stability by Lyapunov like functions of nonlinear differential equations with non-instantaneous impulses, J. Appl. Math. Comput. 53 (1-2), (2015), $147-168$.

[3] R. Agarwal, S. Hristova And D. O'Regan, Non-Instantaneous Impulses in Differential Equations, Springer, 2017.

[4] R. Agarwal, S. Hristova And D. O'Regan, Practical Stability of differential equations with non-instantaneous impulses, Diff. Eq. Appl. 9, (2017), 413-432.

[5] M. U. Akhmetov AND A. Zafer, Stability of the zero Solution of impulsive differential Equations by the Lyapunov second method, J. Math. Anal. Appl. 248, (2000), 69-82.

[6] J. K. HALE, Theory of Functional Differential Equations, Springer, New York, 1977.

[7] J. K. HALE AND V. Lunel, Introduction to Functional Differential Equations, Springer, Berlin, 1993.

[8] J. HENDERSON AND S. HRISTOVA, Eventual practical stability and cone valued Lyapunov functions for differential equations with "maxima", Commun. Appl. Anal. 14, 3, (2010), 515-526.

[9] S. Hristova, Qualitative investigations and approximate methods for impulsive equations, Nova Sci. Publ. Inc., New York, 2009.

[10] S. HRISTOVA, Stability on a cone in terms of two measures for impulsive differential equations with "supremum", Appl. Math. Lett. 23, 5, (2010), 508-511.

[11] S. G. Hristova AND A. Georgieva, Practical Stability in terms of Two Measures for Impulsive Differential Equations with "Supremum”, Inter. J. Diff. Eq. 2011, Article ID 703189, (2011).

[12] S. Hristova And K. Stefanova, Practical Stability of Impulsive Differential Equations with "Supremum" by Integral Inequalities, Europian J. Pure Appl. Math. 5, 1, (2012), 30-44.

[13] V. Lakshmikantham, D. D. Bainov and P. S. Simeonov, Theory of Impulsive Differential Equations, World Scientific, Singapore, 1989.

[14] V. Lakshmikantham And S. LeEla, Differential and Integral Inequalities: Theory and Applications. Ordinary differential equations, Volume 1, Academic Press, 1969.

[15] M. PierRi, D. O'REgAn AND V. RolNiK, Existence of solutions for semi-linear abstract differential equations with not instantaneous impulses, Appl. Math. Comput. 219, (2013), 6743-6749. 
[16] A. Sood And S. K. SRIVASTAVA, On stability of differential systems with non-instantaneous impulses, Math. Probl. Eng. 2015, 2015, Article ID 691687, 5 pages.

[17] I. M. StAmova AND G. T. STAMOv, Lyapunov-Razumikhin method for impulsive functional differential equations and applications to the population dynamics, J. Comput. Appl. Math. 130 (2001), 163-171.

[18] J. WANG AND X. LI, Periodic BVP for integer/fractional order nonlinear differential equations with non-instantaneous impulses, J. Appl. Math. Comput. 46 (2014) 321-334.

[19] J. WANG AND Z. LIN, A class of impulsive nonautonomous differential equations and Ulam-HyersRassias stability, Math. Meth. Appl. Sci. 38, 5, (2015), 868-880. 